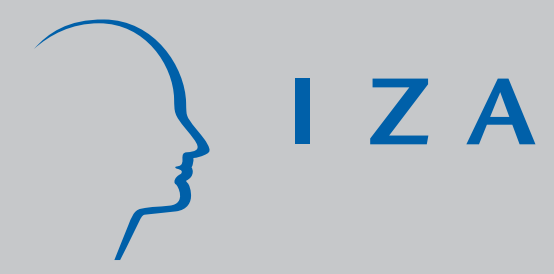

IZA DP No. 3983

Child-Care and Participation in the Labor Market for Married Women in Mediterranean Countries

Catia Nicodemo

Robert Waldmann

J anuary 2009 


\title{
Child-Care and Participation in the Labor Market for Married Women in Mediterranean Countries
}

\author{
Catia Nicodemo \\ Universitat Autónoma de Barcelona \\ and IZA \\ Robert Waldmann \\ University of Tor Vergata
}

Discussion Paper No. 3983

January 2009

\author{
IZA \\ P.O. Box 7240 \\ 53072 Bonn \\ Germany \\ Phone: +49-228-3894-0 \\ Fax: +49-228-3894-180 \\ E-mail: iza@iza.org
}

\begin{abstract}
Any opinions expressed here are those of the author(s) and not those of IZA. Research published in this series may include views on policy, but the institute itself takes no institutional policy positions.

The Institute for the Study of Labor (IZA) in Bonn is a local and virtual international research center and a place of communication between science, politics and business. IZA is an independent nonprofit organization supported by Deutsche Post Foundation. The center is associated with the University of Bonn and offers a stimulating research environment through its international network, workshops and conferences, data service, project support, research visits and doctoral program. IZA engages in (i) original and internationally competitive research in all fields of labor economics, (ii) development of policy concepts, and (iii) dissemination of research results and concepts to the interested public.
\end{abstract}

IZA Discussion Papers often represent preliminary work and are circulated to encourage discussion. Citation of such a paper should account for its provisional character. A revised version may be available directly from the author. 


\section{ABSTRACT}

\section{Child-Care and Participation in the Labor Market for Married Women in Mediterranean Countries}

Parents in the labor force have balance their work and home life, including the choice of the type of care to provide for their children while they work. In this paper we study the connection between the married women's labor force participation, child care arrangements and the time that husbands and wives spent to take care of children in Mediterranean countries. As more women now are in the labor force the interest in the use child care and housework of husband have grown. We use the new database from the EU-SILC (European Survey on Income and Living Conditions) in 2006 and data from the ECHP (European Community Household Panel)in 2001, because these two data-set give us different information about child care and housework. The traditional role of mothers in child care activities is highly valued by many families, especially in Southern European countries. The results show that while Mediterranean countries have advanced in the incorporation of women into the labor market, most of them still have to assume total responsibility for housework and the care of the children. Child care arrangements is an important instrument for women to enter in paid employment.

\section{JEL Classification: J13, J21, C1, C3}

Keywords: $\quad$ unpaid work, child care arrangements, labor supply

Corresponding author:

Catia Nicodemo

Universitat Autonoma de Barcelona

Department of Applied Economics

Campus Bellaterra

08193 Bellaterra (Cerdanyola)

Spain

E-mail: catia.nicodemo@upf.edu 


\section{Introduction}

Family structure and employment patterns have changed in Europe in the last thirty years, so welfare states policies have also changed. European countries have implemented new family policies with a strong effect on parental employment patterns aiming to achieve different objectives such as increasing the participation of mothers in the labour market and the fertility rate, to create the possibility for women to access the labour market on the same footing with men and promoting the equal division of unpaid labour between men and women.

The different work-family arrangements across the member states are based on historical and cultural differences among countries. Esping-Andersen (1990) distinguishes three standard welfare regimens:

\section{1. social-democratic}

\section{2. conservative-corporatists}

\section{3. liberal}

The relationship between the labour market, the family and the welfare state varies among countries.

Mediterranean countries were classified by Esping-Andersen in the second type of welfare-state regimes. Women were primarily responsible for unpaid work at home and the tradition family was central in this regime. Child care and other unpaid work were unequally shared among partners, even when mothers were employed on a full time basis in the labour market. We focus our attention on these countries and study if there is a change in this regime as for the welfare state in family policies, unpaid work at home (including child care) and the labour market participation of married women or there is still a conservative regime. Countries analyzed in this work are: France, Italy, Spain, Portugal and Greece. 
The increase of the participation rate of women in the labour market has implied one change in the traditional family. Their members have to decide how the housework is to be distributed and who is to take care of children, because the structure of the household where the wife does the housework and takes care of the children, and the husband works outside to earn the household income changed, even if partially.

The increased number of women in the labour force has made possible not only an egalitarian distribution of the household work within the household but the interest in the use of non-parental child care has grown. The intervention of governments that have subsidized child care programs in the form of pre and after school programs, or the help of an informal arrangements such as grandparents and professional child-minders, have enabled women to participate in paid employment, because child care represents a potential cost for the family. Decisions concerning the use of non-parental child care depend on many economic and demographic factors, and the process by which these decisions are made has implications for the effectiveness of social policy concerning child care. Efforts to increase the supply of child care must take into account the factors that parents demonstrate as important in their choices of what child care to use.

In table 1 we present the maternal employment rate in 2005 with respect to age and number of children in Europe. We can see that most mothers are in paid work especially when they children go to school.

A large number of papers in the past years have studied the link between women employment, child care cost and husbands' housework time. Bianchi et al. (2000) studied how the propensity to do housework has increased during 1965 and 1995. Coverman (1995) found that husband housework time is correlated with wives' employment status. Alvarez-Miles (2006) investigated the Spanish data to analyze the decision of women to enter in paid employment.

The literature on and labour supply has focused on the effect of child care costs. Heckman (1974), Blau and Robins (1988), Connelly (1992) among 
Table 1: Maternal employment rates, women age 15-64

\begin{tabular}{|c|c|c|c|c|c|c|c|}
\hline \multirow[t]{2}{*}{ Country } & \multicolumn{4}{|c|}{ by age of youngest child } & \multicolumn{3}{|c|}{ by number of children under 15} \\
\hline & $0-16$ & $<\mathbf{2}$ & $3-5$ & $6-16$ & 1 child & 2 children & 3 children \\
\hline Belgium & 59.9 & 63.8 & 63.3 & 56.9 & 58.3 & 58.5 & 39.4 \\
\hline Canada & 70.5 & 58.7 & 68.1 & 71.1 & 70.1 & 73.2 & 66.3 \\
\hline Czech Republic & 52.8 & 19.9 & 50.9 & 67.6 & 57.4 & 52.5 & 34.4 \\
\hline Denmark & 76.5 & 71.4 & 77.8 & 77.5 & & & . \\
\hline Finland & 76.0 & 52.1 & 80.7 & 84.2 & 71.2 & 70.9 & 60.1 \\
\hline France & 59.9 & 53.7 & 63.8 & 61.7 & 62.2 & 57.6 & 38.1 \\
\hline Germany & 54.9 & 36.1 & 54.8 & 62.7 & 58.4 & 51.8 & 36.0 \\
\hline Greece & 50.9 & 49.5 & 53.6 & 50.4 & 48.4 & 44.4 & 37.4 \\
\hline Hungary & 45.7 & 13.9 & 49.9 & 58.3 & 53.7 & 48.3 & 24.6 \\
\hline Iceland & 84.8 & \multicolumn{2}{|c|}{83.6} & 86.5 & 88.5 & \multicolumn{2}{|c|}{82.3} \\
\hline Ireland & 57.5 & \multicolumn{2}{|c|}{55.0} & 59.9 & 55.4 & 52.5 & 42.3 \\
\hline Italy & 48.1 & 47.3 & 50.6 & 47.5 & 48.3 & 41.0 & 27.4 \\
\hline Japan & 52.4 & 28.5 & 47.8 & 68.1 & & & \\
\hline Luxembourg & 55.4 & 58.3 & 58.7 & 52.7 & 56.0 & 49.8 & 33.8 \\
\hline Netherlands & 69.2 & 69.4 & 68.3 & 69.4 & 70.1 & 70.6 & 59.9 \\
\hline New Zealand & 64.6 & 45.1 & 60.6 & 75.3 & 64.1 & 64.5 & 56.7 \\
\hline Poland & 46.4 & ... & .. & 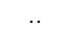 & 42.7 & 35.6 & 28.5 \\
\hline Portugal & 67.8 & 69.1 & 71.8 & 65.4 & 63.5 & 59.2 & 46.1 \\
\hline Slovak Republic & 48.4 & 23.1 & 46.6 & 60.4 & 56.4 & 49.4 & 31.5 \\
\hline Spain & 52.0 & 52.6 & 54.2 & 50.9 & 51.1 & 44.7 & 38.5 \\
\hline Sweden & 82.5 & 71.9 & 81.3 & 76.1 & 80.6 & 84.7 & 75.6 \\
\hline Switzerland & 69.7 & 58.3 & 61.7 & 77.0 & 69.5 & 65.4 & 58.0 \\
\hline United Kingdom & 61.7 & 52.6 & 58.3 & 67.7 & 67.1 & 62.4 & 42.3 \\
\hline United States & 66.7 & 54.2 & 62.8 & 73.2 & & & \\
\hline EU-19 & 59.5 & 51.1 & 58.2 & 63.2 & 59.4 & 55.2 & 41.2 \\
\hline OECD average & 61.5 & 51.7 & 61.2 & 66.1 & 60.2 & 56.9 & 43.8 \\
\hline
\end{tabular}

others found that female labour participation is significantly influenced by child-care policies in the U.S and UK.

A very limited number of works have investigated which effect have child care arrangements and husbands' housework on employment of wives in particular for Mediterranean countries where family traditions have changed dramatically in this last decade.

It once was difficult to find data on arrangements in Europe, but with the new data set of EU-SILC (European Income and Living Conditions) we have this information. To do the cross-section analysis we use the 2001 wave from the European Community Household Panel (ECHP) and the EU-SILC in 2006 .

In this contest the objectives of the paper are threefold. First, to study the household model in Southern European countries, how the members of a family share the housework and how they take care of children, has changed something in these countries or continue to be a conservative welfare regime. Second, how non-parental arrangements are used by the household. We distinguish two types of arrangements: paid care (day centre care, professional child-minders and centre-based services) and unpaid care (grandparents and 
others household members). Finally, we investigate how child care arrangements affect the participation equation of married women in the labour market. Mediterranean labour and child care market are very rigidity and inflexible where take the decision for the mothers to enter in the labour market and to use child care is very complicated.

The paper is organized as follows: in section I we present summery statistics and analysis of child care arrangement and hours spent in take care of children. In section II we estimate a probit model to carry out the characteristics that determine the time dedicated to caring for children, and in section III we estimate the impact of child care arrangements on employment status of married female and conclusions.

\section{Sample Characteristics and Data}

The data set used is drawn from the European Community Household Panel (ECHP) and EU-SILC (European Income and Living Conditions).

The ECHP data set is a multi-country annual longitudinal survey of collected data since $1994^{1}$ in 15 European Union Member States under Eurostat (Statistical Office of the European Communities) coordination.

The data set covers approximately 130,000 individuals from 60,000 households in the fifteen countries which were EU members in 2000, reflecting population changes over time through a continuous evolution of the sample. The panel data cover a wide range of subjects such as demographics, labour force behavior, income, health, education and training, housing, poverty and social exclusion, etc.

The ECHP is being progressively replaced with data collection under the EU-SILC regulations (no.1177/2003 Community Statistics on collection under the EU-SILC regulations on Income and Living Conditions). Seven countries launched a preliminary version of the EU-SILC in 2003. The project was formally launched in 2004 and EU25 coverage is expected with

\footnotetext{
${ }^{1}$ Belgium, Germany, the Netherlands, the U.K., Denmark, France, Greece, Ireland, Portugal, Italy and Spain started in 1994 (wave 1), Austria joined in 1995 (wave 2), Finland joined in 1996 (wave 3).
} 
effect from $2005^{2}$. The regulations will be fully applicable from 2007. EUSILC is expected to become the reference source of statistics on income and social exclusion in the European Union.

The European Union Statistics on Income and Living Conditions (EUSILC) aims to collect timely and comparable cross-sectional and longitudinal multidimensional microdata on income, poverty, social exclusion and living conditions.

The EU-SILC aims to provide two types of data:

- Cross-sectional data pertaining to a given time or a certain time period with variables on income, poverty, social exclusion and other living conditions .

- Longitudinal data pertaining to individual-level changes over time, observed periodically over, typically, a four year period.

Social exclusion and housing condition information is collected at household level while labour, education and health information is obtained for people aged 16 and over. The core of the study, income at a very detailed component level, is mainly collected at personal level but a few components are included in the household part of SILC.

The sample has been constructed by matching the couple of wives with their respective husbands. We have selected all $t$ wives who are in working age and we have excluded self employed women. The size of the sample varies across countries and across years.

First, we look at the percentage of households by reference to the spouses' relationships with the labour market. Figure 1 relates to the employment patterns of husbands and wives in 2001 and 2006 elaborated respectively with ECHP and EU-SILC data. We can see how the part-time employment is very low for husbands in these years, while for wives it has increased and France is the country with a major number of women in a part-time job.

In table 3 and 4 we report for each country the husbands' and wives' relationships with the labour market in 2006 estimated with the EU-SILC

\footnotetext{
${ }^{2}$ The EU-SILC was launched in 2004 in 13 Member States :BE, DK, EE, EL, ES, FR, IE, IT, LU, AT, PT, FI and SE and in NO and IS
} 
Figure 1: Employment patterns by full-time and part-time for husbands and wives
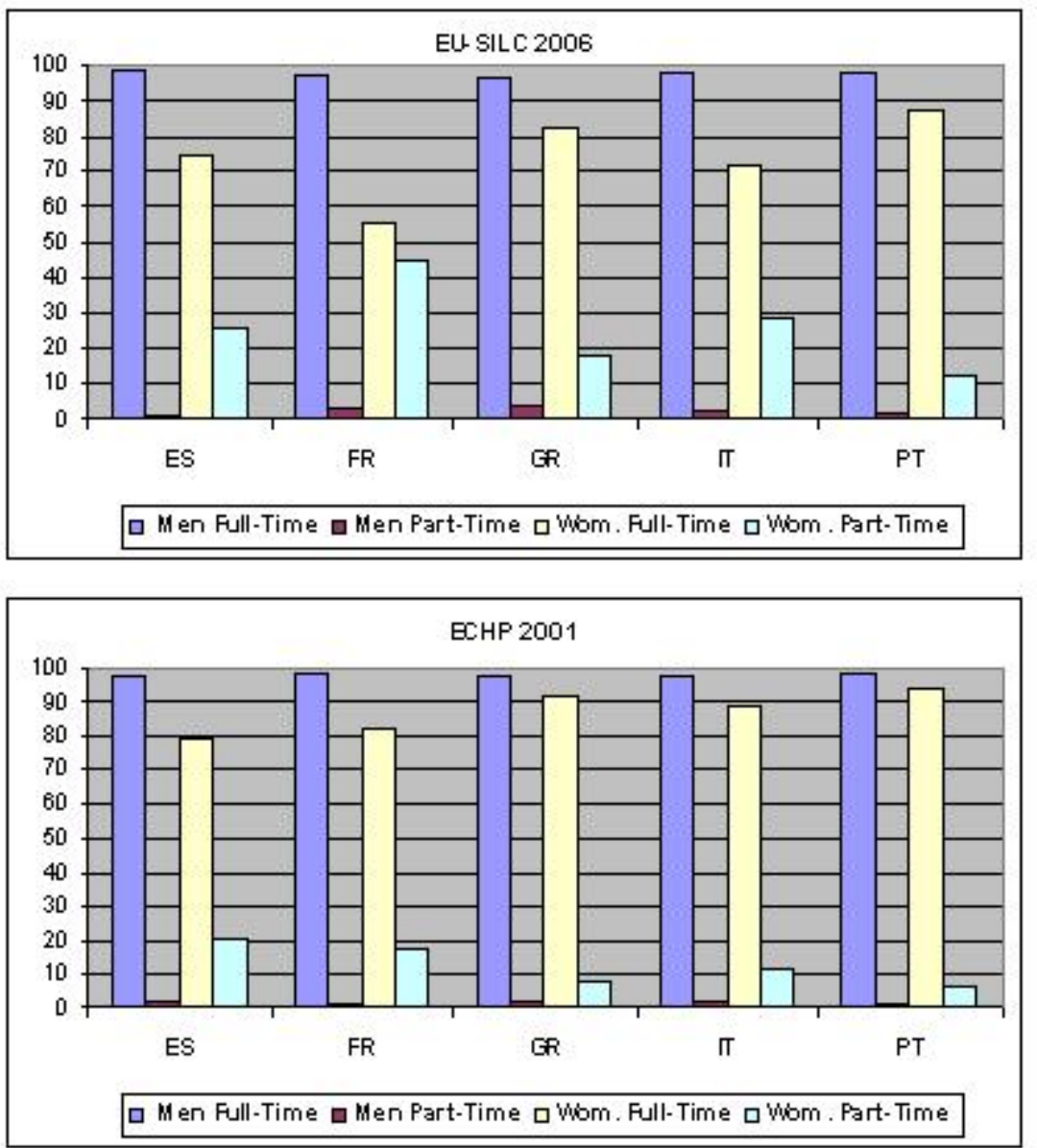
data set and in 2001 estimated with the ECHP data.

Regarding husbands that work at home, the data show that it is very rare to find men at home, just Italy and Spain have a few husbands in this situation in the EU-SILC data while in Greece and Portugal we continue to find no husbands who spent time in this job in 2006.

Women's housework decreased in 2006 with respect to 2001 around $10 \%$ in all countries and about $20 \%$ in Greece. The unemployment rate affects women more than men and it decrease in general, while the employment rate increased in 2006 and we find a difference between husbands and wives, with a difference of $40 \%$ of participation in the labour market for Greece, Italy and Spain and about 20\% for Portugal and France. These tables show that the family behavior has changed, but the results are more clear in tables 5 and figures 2 to 4 where we look at the time spent by wives and husbands taking care of children in 2001 with ECHP data and the time that children spent in non parental when they are (pre-after) school hours outside with EU-SILC data in 2006. ${ }^{3}$.

In table 5 we present data on how husband and wife shared the time that dedicated to care of the children and the time that they spent on child care in 2001. We can first note that such care is distributed between both spouses unequally in all countries. $70 \%$ of wives spend time on this task in Mediterranean countries and $50 \%$ of husbands, but when the wives do not take care of children only $0.50 \%-1 \%$ of their partners do. Women dedicated much more time to child care, we find that $88 \%$ of women in Spain spent more than 28 hours for children while only $45 \%$ of men spent 28 hours. We don't find striking differences across countries except for France where a higher percentage of husbands take care of children although the time spent with children is less for both spouses.

\footnotetext{
${ }^{3}$ In the data set EU-SILC, we don't have the variable that indicate the number of hours that the members of the household spent taking care of children, but the number of hours that the children spent outside the home such as in care organised/controlled by a structure (public, private), direct arrangements between the carer and the parents, unpaid care (free or informal arrangements such as exchange of services) as grand-parents, others household members (outside parents) and centre-based services outside (pre-)school hours
} 
We show the results of the EU-SILC data in figure 2, 3 and 4 and table 2 where we report the weekly hours that children with age between 0 and 13 spent in arrangements such as institutions, with professional babysitters or using informal care and the distribution of child care arrangements for each Mediterranean country. Preschoolers and grade school-aged children required different types of care.

The child care system is organized differently across countries, in table 2 we report the average of hours that children spent in a week in different types of care. We have Child care at centre-based services, that concerns only the children who are at pre-school or at school if the child care reference time is outside (pre-)school hours. Child care at day-care centre includes all kinds of care organised/controlled by a structure (public or private). Child care by a professional child-minders where the arrangements are direct between the care provider and the parents: parents are often employers and pay the care provider directly. Unpaid care are free or informal arrangements such as exchange of services (neighbor, friends, grandparents etc.) Unpaid care is used in all countries. Greece and Italy are the countries where the percentage of the children in the unpaid care is highest ( $73.25 \%$ and $54.91 \%$ ) and where the children spent by average 20 hours per week in Greece and 15 hours in Italy. France and Portugal have a high number of children in daycentre care, where children spend time during pre and after school hours, while Spain and Greece do not use this type of child care a lot. Professional child-minders are an option that parents use and where children stay a long time except in Portugal and Italy where the hours are around 8 per week.

If we look at graphs 2-4 we find that the distribution of the age of children with respect to hours spent in non parental child care arrangements varies across countries and decreases with age. We can see that the period between 0 and 6 years is a critical age, since children require more hours of care. When children are older than 10 the number of hours spent in child care is less. In Italy and Spain non parental child care arrangements used less than in other countries in each age cohort, while in Portugal we find that a great 
percentage of the children in the middle, $3-10$ years old, receive care away from their parents.

We can conclude that the time that children spent without parents is not very high especially for Italy and Spain and in particular when children are in grade school.

In the following figure 5, we present the child care arrangements by mother's working status. Grandparents play an important role as primary child care especially when the mother is employed. In Portugal and France almost $90 \%$ of women work outside the home while in the rest of countries surprisingly a $10 \%$ of women work at home and use child care. Children are care by the day-centre care or by the centre-based services while women work at home or are unemployed in Italy, Greece and Spain. The percentage of women who have a paid job is very high when they use the professional child-minders services, maybe because this kind of arrangements is very expensive and located in large cities where people's living standard is high and so the mother often has a high salary.

This effect is confirmed if we look at graph 6 where we take in consideration the households income by child care arrangements. The mean income of household using professional child-minders is high in all countries, while is low when parents use unpaid care, except for Portugal which has the same distribution of household income across different types of child care.

For many families, however, there are additional arrangements made for child care. We have calculated the number of types of non parental child care used by parents in Mediterranean countries and the results are reported in graph 7. In Spain, Portugal and Greece a 90\% of households only use one kind of non parental child care while France and Italy more than $25 \%$ use also another second kind of non parental child care. 
Figure 2: Distribution of the number of hours spent in a week in child care arrangements: EU-SILC 2006
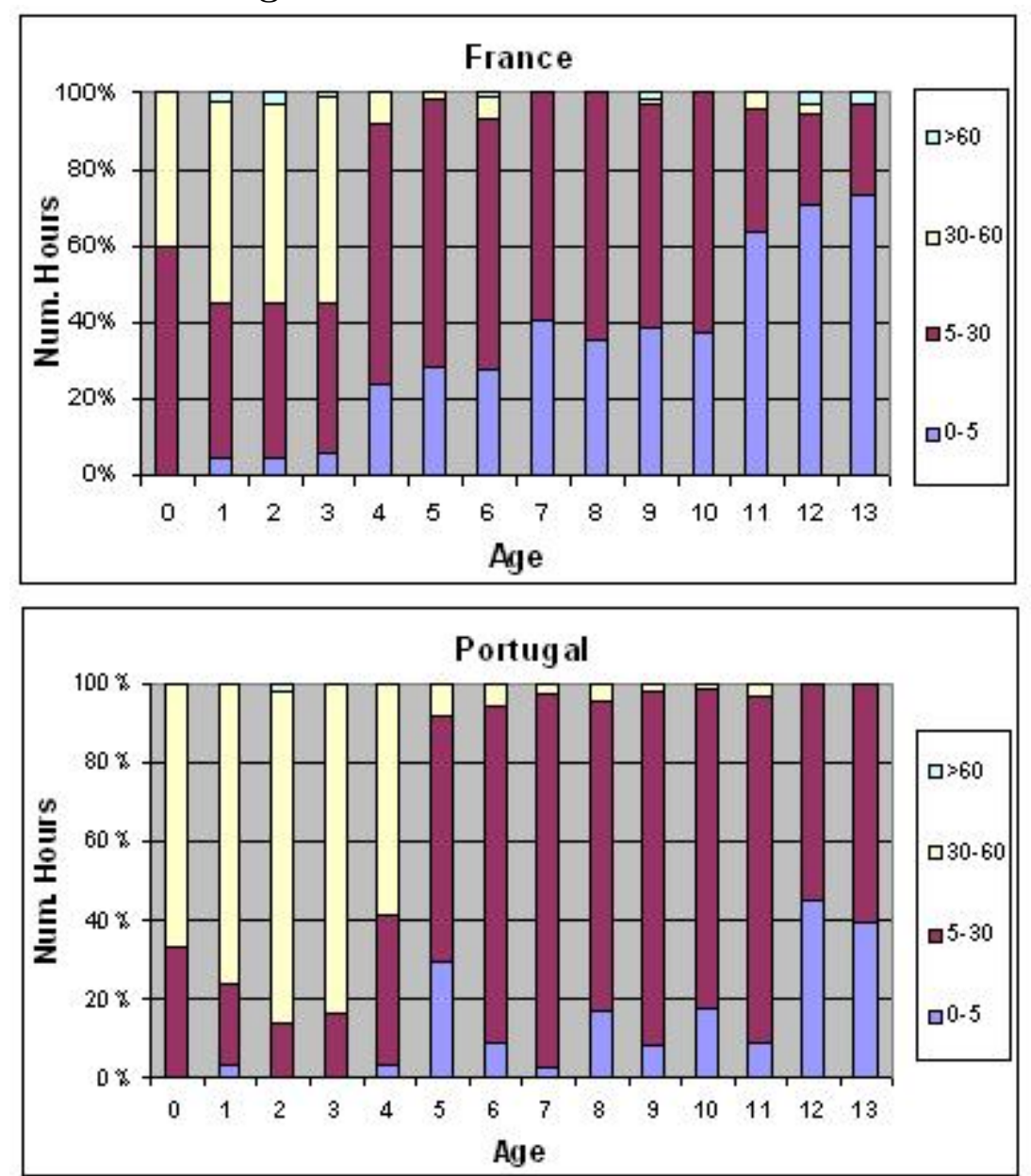
Figure 3: Distribution of the number of hours spent in a week in child care arrangements: EU-SILC 2006
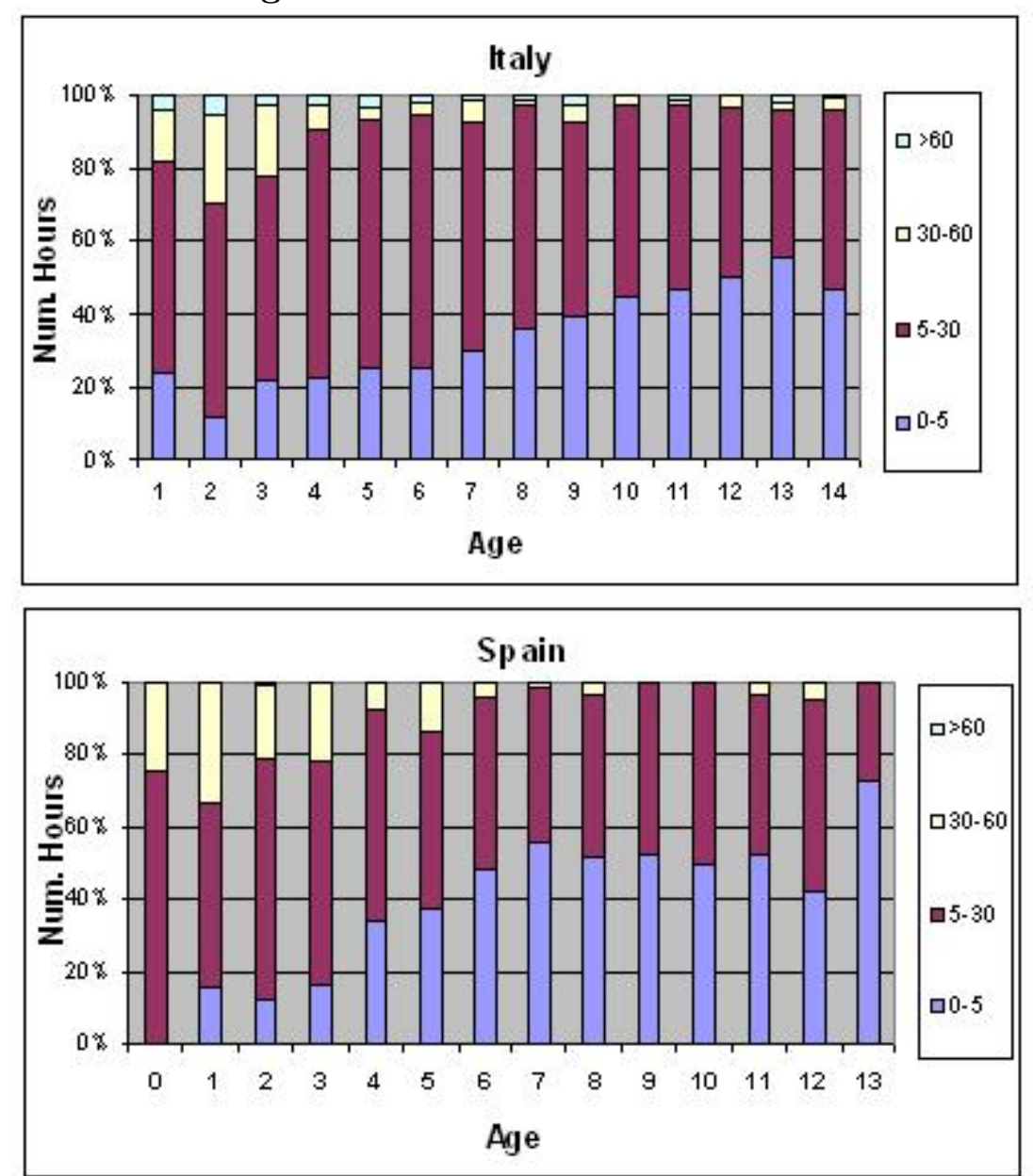
Table 2: Distribution of Child care Arrangements: EU-SILC 2006

\begin{tabular}{ccccc}
\hline Country & $\begin{array}{c}\text { Centre- } \\
\text { based } \\
\text { services }\end{array}$ & $\begin{array}{c}\text { Day- } \\
\text { centre } \\
\text { care }\end{array}$ & $\begin{array}{c}\text { Profes- } \\
\text { sionals } \\
\text { child- } \\
\text { minders }\end{array}$ & $\begin{array}{c}\text { Unpaid } \\
\text { care }\end{array}$ \\
\hline \hline Spain & 5.21 & 14.89 & 18.26 & 16.21 \\
& 30.24 & 9.41 & 15.12 & 45.24 \\
France & 5.68 & 21.44 & 18.43 & 12.18 \\
& 27.75 & 24.49 & 17.18 & 30.57 \\
Greece & 11.39 & 12.33 & 25.21 & 24.49 \\
& 17.74 & 0.43 & 8.58 & 73.25 \\
Italy & 5.81 & 4.28 & 10.02 & 14.43 \\
& 21.56 & 16.86 & 6.65 & 54.91 \\
Portugal & 12.01 & 36.5 & 24.44 & 21.14 \\
& 41.52 & 14.84 & 7.95 & 35.69 \\
\hline \hline
\end{tabular}

Figure 4: Distribution of the number of hours spent in a week in child care arrangements: EU-SILC 2006

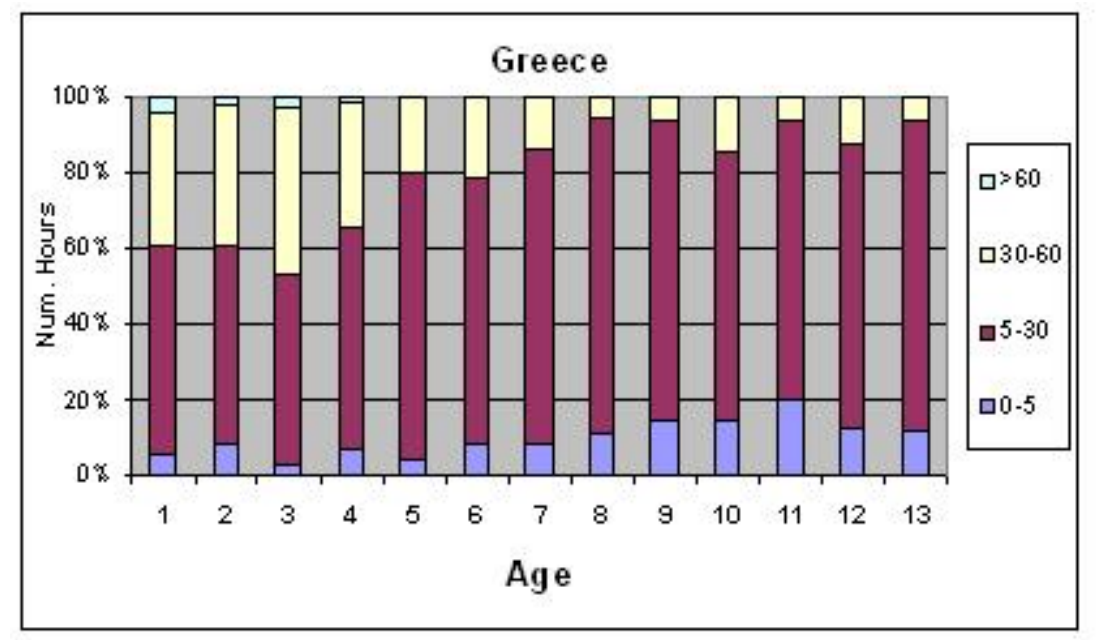


Figure 5: Child care Arrangements by Mother's Working Status
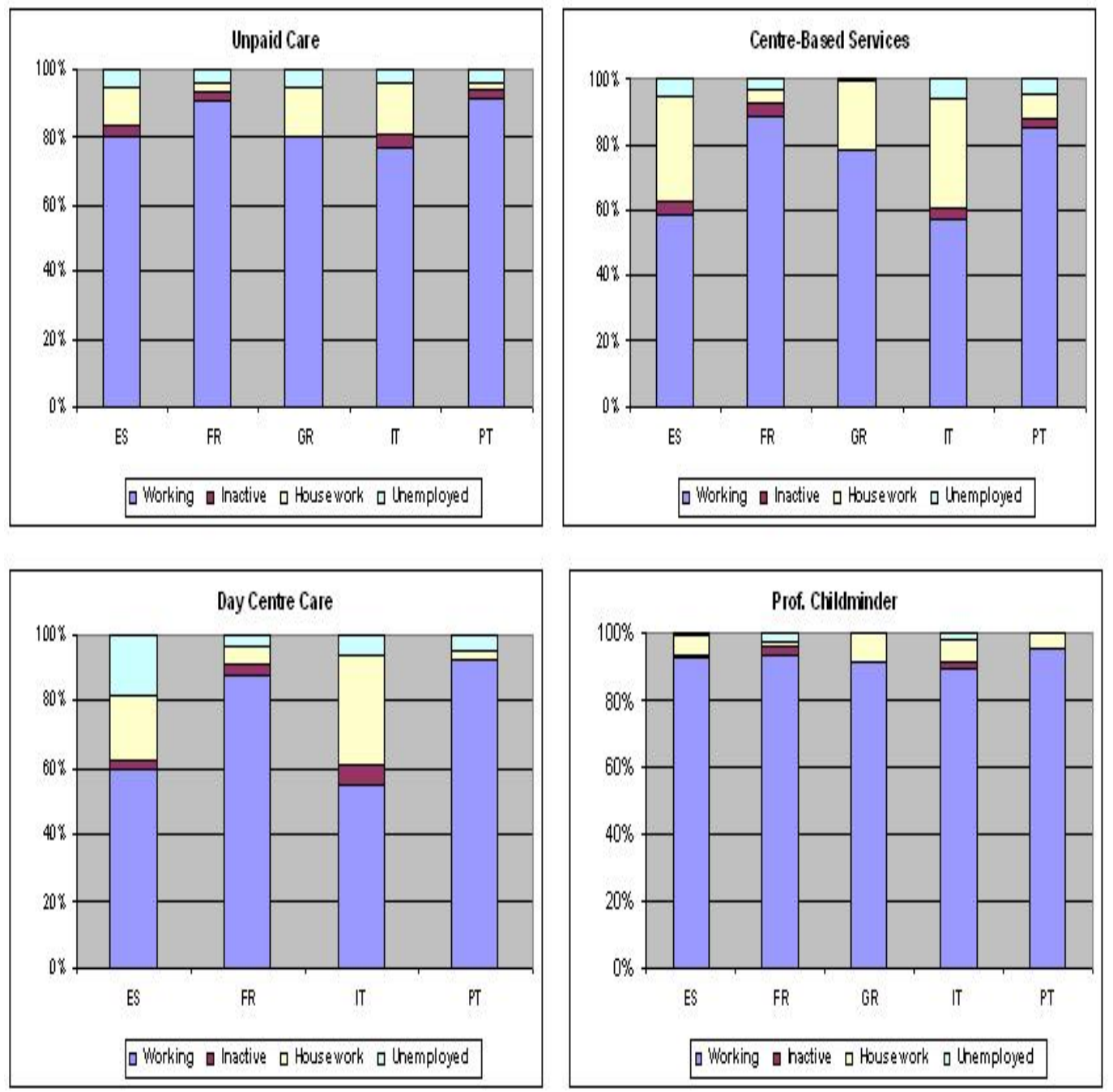
Figure 6: Household Income by Child care Arrangements

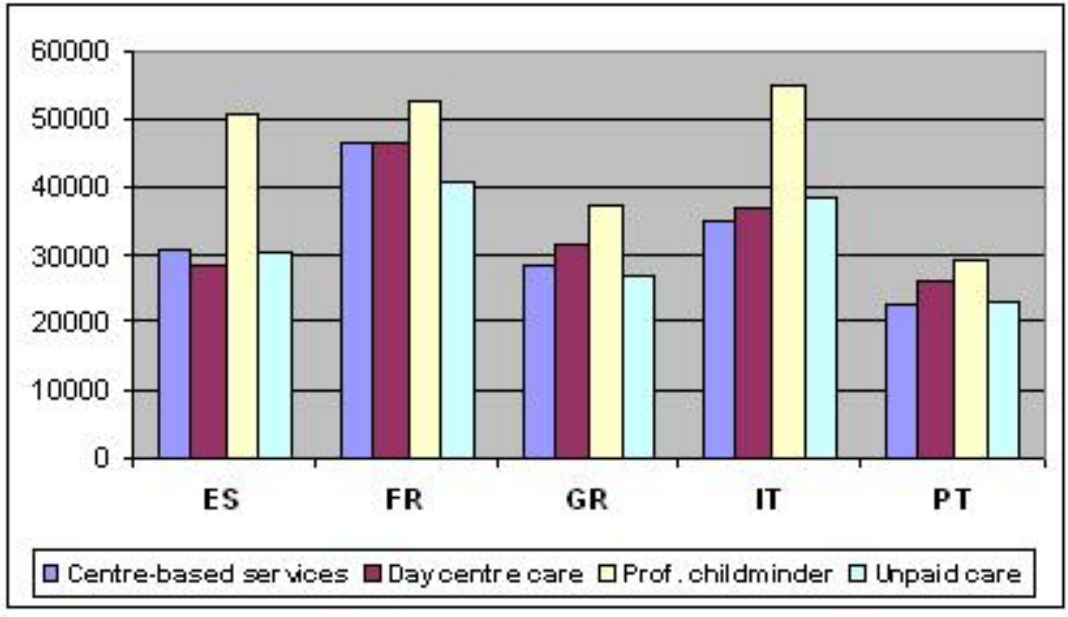

Figure 7: Number of Child care Arrangements Used: EU-SILC 2006

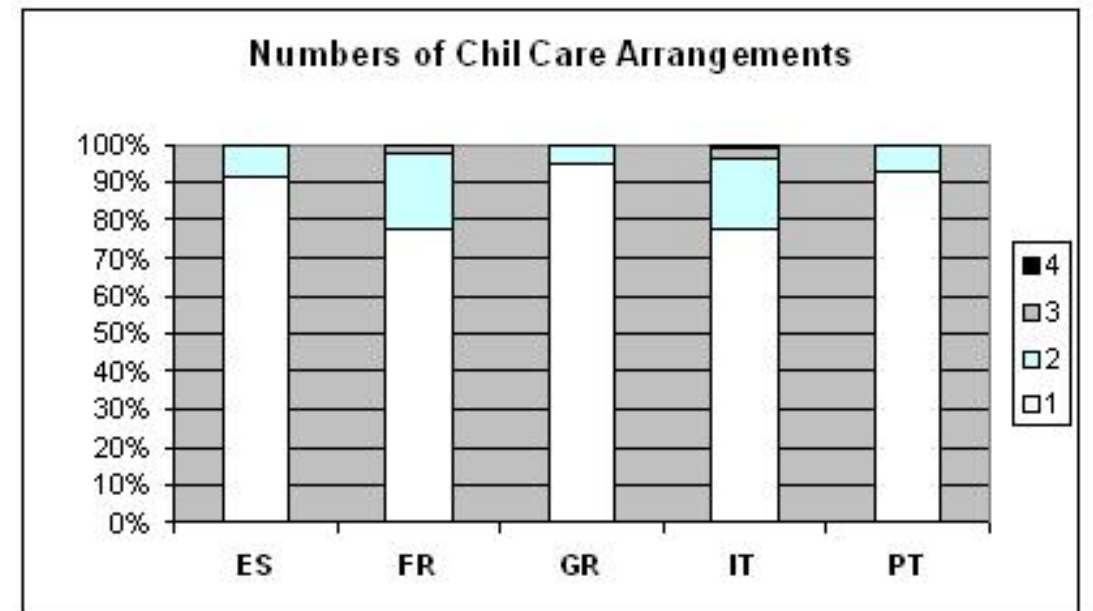




\section{Theoretical Model of Employment Decision and Child Care}

Our propose is to study the impact of child care on women's employment decision. We focus our attention on the maximization of utility function that mothers do when they decide to enter in the labour market. We do not present a formal theoretical model of child care and employment but follow a simple microeconomic model of time allocation. The total time $(K)$ that mothers have is fixed and limited and is allocated in two uses: work $(H)$, that is repay at a fixed wage $w$ and leisure $(L)$.

$$
K=L+H
$$

Hours of labor are chosen to maximize an utility function that depends on leisure and consumption, $C$, subject to a budget constraint that is composed by no labor income $W$ and wage rate $w$. A part of the mother's leisure is used to take care of children if they are present in a family. The children could also receive care from market(paid) and no-market (unpaid) systems. Hours that children spend in paid care are denoted as $F$ and hours spend in unpaid care are denoted as $I$. Let $\alpha_{L}, \alpha_{F}, \alpha_{I}$ represent the productivities of maternal care, market care and no-market care respectively. The total care that the child $i$ receive can be expressed as:

$$
Q_{i}=\alpha_{T} L_{i}+\alpha_{F} F+\alpha_{I} I
$$

Paid child care has a price $(p)$ measured as a percentage of consumption goods $(C)$ and it also has to be incorporated into budget constraint. In our data we do not know this price p, but only the hours that children are cared away from their parents. The budget constraint in a family is given by:

$$
C=W+w H-p F
$$


We don't know this $p$ and the price of unpaid care is equal to zero. The income of other components of the family is included in $W$ and considerated as exogenous, so we can rewrite the budget as:

$$
C=W+w H
$$

The household utility function can be maximized as:

$$
\max _{(H, F, I)} U=U\left(\alpha_{L} K-H+\alpha_{F} F+\alpha_{I} I, K-H\right)
$$

The solution of this maximization problems conduct to first order conditions that resume the relationship among the choice variable : $H, F$ and $I$ are given by these reduced form solutions:

1.

$$
H=(W, X, \epsilon)
$$

2.

$$
F=f(W, X, \gamma)
$$

3.

$$
I=i(W, X, \eta)
$$

Where $W$ is the wage, $X$ is a vector of observed characteristics, and $\epsilon, \gamma$, and $\eta$ represent unobserved terms normally distributed. As we have commented before, we do not take in consideration the cost of child care because we do not have this information in our data-set, of course the family utility depends also on the price of paid child care but we must omit this part.

The decisions to enter the labour force $H$ and use child care $(F, I)$ are interrelated. Our approach models child care decision as conditional on the women's labour force participation using a multivariate selection model, 
where we estimate jointly the choices of child care and labor supply with the following model:

$$
\begin{aligned}
& y_{1}=1\left(\alpha_{y 2}+x_{1} \beta_{1}+\varepsilon_{1}>0\right) \\
& y_{2}=1\left(x_{2} \beta_{2}+\varepsilon_{2}>0\right), \\
& y_{3}=1\left(x_{3} \beta_{3}+\varepsilon_{3}>0\right), \\
& \left(\varepsilon_{1}, \varepsilon_{2} \varepsilon_{3} \mid x_{1}, x_{2}, x_{3}\right) \sim N(0,1, \rho),
\end{aligned}
$$

where $1($.$) is the indicator function taking the value one if the state-$ ment between brackets is true and zero otherwise. $\beta_{1}$ and $\beta_{2}$ are regression coefficients, and indicate the standard bivariate normal distribution with correlation coefficients. When $\rho$ is zero, the model for $y_{1}$ reduce to the standard probit model. Consistent and asymptotically efficient parameter estimates are obtained by maximum likelihood estimation of multi-equation, conditional recursive mixed process estimators. "Mixed process" means that different equations can have different kinds of dependent variables. This is based on a likelihood function consisting of a product of individual contributions of the type:

$$
\begin{aligned}
& L_{i}\left(\alpha, \beta_{1}, \beta_{2}, \beta_{3} \mid y_{1 i}, y_{2 i}, y_{3 i}, x_{1 i}, x_{2 i}, x_{3 i}\right)= \\
& =P\left(y_{1 i}, y_{2 i}, y_{3 i} \mid x_{1 i}, x_{2 i}, x_{3 i}\right)
\end{aligned}
$$

The participation equation is estimated with a probit model and can be written as:

$$
\begin{aligned}
& H^{*}=\beta W+\beta X_{i t}+\epsilon \\
& H=1 \quad \text { if } \quad H^{*}>0
\end{aligned}
$$

where $H$, is a dummy variable that takes 1 if the woman participates in the labour market (working or seeking work) and 0 if she doesn't. We excluded self-employed married women. The decision to participate depends on a vector of explanatory variables $X_{i t}$ such as age, education level, hourly 
wage, household income without wife's earnings, household size, education of husbands, if the husband are unemployed or not, urbanization of area, having or not children with different level of age and type of child care: paid and unpaid. Wages of mothers are observed only if they are in the job market.

The equation of paid child care $(F)$ depends on the age of children, utilization of unpaid care, hourly wages, family income, while the equation of unpaid child care $(I)$ is estimated on the age of children, wages, family income and utilization of paid care.

Conditional on the mother's employment(working or not), the two equations of child care (paid and unpaid) are estimated as a joint Tobit model. In total, the model contains five states. First we have the state where women decide not o enter in the labour market, and after other four states if they decide to enter. The four combinations are: $-1-$ utilize both paid and unpaid care, $-2,3-$ utilize only one of type of care (paid or unpaid) and $-4-$ utilize no care.

\section{Time Dedicated to Taking Care of Children and the Type of non Parental Child Care Arrange- ments Used}

First, we estimate the probability for husbands and wives to take care of children with a probit model on the data set from the ECHP in the year 2001. Second using the wave of 2006 of the EU-SILC data we calculate with a multinomial logit the probability of using one type of child care arrangement with respect to the others.

In the probit model we calculate $P_{i t}$, which denotes the probability that an individual $i$ takes care of children in the period $t$.

$$
y_{i t}^{*}=\beta^{\prime} x_{i t}+\varepsilon_{i}
$$

In practice, $y_{i t}^{*}$ is unobservable if :

$$
y_{i}=1 \text { if } y_{i t}^{*}>0 \text { and } y_{i}=0 \text { if } y_{i}^{*} \leq 0
$$




$$
\varepsilon_{i}(0,1)
$$

where $x_{t}$ is a vector of individual characteristics at age $t$, and $\beta$ is a row vector of coefficients. For the probit model we assume $\varepsilon_{i}$ follows a standard normal distribution. The corresponding density and distribution function of the normal are given by:

$$
\begin{gathered}
f(w)=\phi(w) \\
P\left(w<w^{*}\right)=F\left(w^{*}\right)=\Phi\left(w^{*}\right)
\end{gathered}
$$

where this last equation is the cumulative value of the normal distribution. We utilize a simple specification of the labour supply function focusing on demographic characteristics. The probit model is estimated for husbands and wives using the ECHP data. The vector of individual characteristics $x_{t i}$ at time $\mathrm{t}$ contains the following variables: age in three different age cohorts; dummy variables for three different level of education: primary school, secondary school and tertiary school; the status of employment (at work, unemployed and housework or inactive) and variables for the spouse: level of education and employment status. Finally we used variables at the level of the household such as the logarithm of the household income without the partner's earnings and the household size.

In table 6 we report the marginal effects of the probit estimation of positive time dedicated to taking care of children using the ECHP survey in 2001 for the selected countries.

We can note that husbands and wives's decision is influenced by age in all countries. We find that the probability to take care of children decreases with age, although husbands and wives presented an inverted U-shape in France and Spain, the probability first increases with the age then in a middle age decreases. This probability increases also when the education level of women decreases and the education level of men increases except for French wives. If we look at the employment status, the results suggest that the probability of taking care of children increases if the wife or the husband 
work at home and decreases when spouses are at home. Of course we find a correlation between taking care of children and employment status, but in this case we only want to describe the pattern and not address casuality. Income has a positive effect for husbands in Italy, Portugal and for French and Portuguese wives, while for the rest of countries the effect is negative. The household size has a positive and significant effect on the time spent with children for both partners. So we noted that wives who dedicate a lower number of hours in the labour market are able to dedicate more time to taking care of children. These results are in accordance with other papers dedicated to this topic, for example in Spain with Garcia - Molina (1998) and in Italy with Del Boca (2002).

With the EU-SILC data in the year 2006 we first calculated the probability for children to use a kind of non parental child care arrangement. To calculate this probability we use a multinomial logit model.

The multinomial logit model is a logistic regression where the response variables are more than two categories, it is a multiequation model where the individual $i$ choose alternative $j$ to maximize the utility function:

$$
U_{i j}=\max \left(U_{i 1}, U_{i 2}, \ldots \ldots, U_{i j}\right)
$$

where the utility depends on some individual characteristics $X_{i}$ :

$$
U_{i j}=\beta_{j} X_{i}+\varepsilon_{i j}
$$

and the probability is:

$$
\operatorname{Pr}(\text { alternative } j)=\operatorname{Pr}\left(U_{i j}>U_{i k} \quad \forall j \neq k\right)
$$

The results are showed in table 7 , where the dependent variable takes four values corresponding to the types of child care. We have selected unpaid child care as the base category, that is, the comparison group. As explanatory variables we use the characteristics of the father and mother such as: education and age, the income of the family, the age of children and the grade of urbanization. 
The age of children decreases the probability to use professional childminders in all countries except in Italy where the value is not statically significant, and increases the probability to choose centre-based services. The education level of mothers and fathers and household income increases the probability to chose professional child-minders while the probability to choose the center-based services and day-centre care decreases, except in France for the day-centre care. The degree of urbanization allows that parents choose day-centre care and based-service with respect to informal care.

This analysis also reflects the quality of child care that is offered on the market and the level of trust that parents have in these types of child care arrangements. More income and more level of education encourage parents to use professional child care more than informal care.

\section{Results}

In this part of the paper we estimate the effects of non parental child care on the employment status of women (and vice versa) and the opportunity cost of the time dedicated by the household to taking care of children. The participation equation is expressed as a probit while the hours of paid and unpaid care utilization are estimated with a Tobit model. All three equations are estimated simultaneously using a method of maximum likelihood. We present two results of the join of employment status and care utilization. The first model is an estimation of the probit participation of women joint with child care arrangements, paid and unpaid. In the second model results take in consideration also the hourly wage. We report only results for Italy ${ }^{4}$.

Table 8 contains the joint estimation of the three equation models. The first column reports the estimation of the participation of married women in the labour market. Age of women and their education tend to increase the probability to work, as well as the education of the husband. These results also indicate that if wives have children they are not able to work, especially when children are less than 6 years old. Income has a positive effect on this

\footnotetext{
${ }^{4}$ Other countries results are available on request to the author.
} 
probability such as if the husband does not work and the metropolitan area.

The second column in table 8 show the coefficients of hours that children spent in paid child care. The age of mothers and the education of both parents have a positive and significant effect on the utilization of this kind of child care arrangement.

The age of children has a negative effect, especially when children are very young. This could depend on various factors: the scarce presence of child care system in Italy for children with age less than three, children with 0-3 years are more likely to be cared from informal care and another factor may be the high level of tradition in families present in this country. Husbands that stay at home because are unemployed, reduce number of hours of paid care utilization.

The last column is the estimation of the utilization of unpaid care. Age and education of mother and education of fathers increase the number of hours that children spend in child care. Young children are estimated to have a positive and strong effect on unpaid care. The utilization of unpaid care decreases when children are more independent. Numerous family discourage the utilization of unpaid care such as an husband with an unemployment status.

In Table 9 we insert in the simultaneous equations model the prediction of hourly wage. The mother's wage is observed only for those who work, so we need to correct the selection bias, estimating first the participation equation to calculate the inverse Mill's ratio $(\lambda)$ and after calc ulating the prediction of the correct wage equation using the $\lambda$ (see Heckman 1973). The wage has a positive effect in the use of child care arrangement and in the participation to the job market.

The age is positive and significant in all three equations, while its square is negative. The level of education increases, which makes women more likely to work and to use paid and unpaid child care. The presence of children increases the probability to use unpaid child care with respect to paid child care and at the same time it reduces the probability of working. Also the 
house size decreases this probability. The positive sign of no labor income is associated with an increment of the probability to enter in the job market for women, while paid and unpaid child care are considerated as normal goods. The hourly wage of husband in one side decreases the probability for women to enter in the job market and in the other side increases hours utilization of child care arrangements.

\section{Conclusion}

In this paper we have studied the relationship between women's employment status and child care arrangements, and the time that parents spend with children in Mediterranean countries. The results show that while Mediterranean countries have advanced in the incorporation of women into the labour market, most of them continue to assume total responsibility for housework and most responsibility for the care of the children.

We observe how the probability to take care of children increases with the age and if one of partner is unemployed, and decreases with the age of children and parents level of education. Normally in the house women are responsible for this task.

To have a child care arrangement and in particular grandparents who help taking care of children is correlated with having more time to participate in the labour market, but in countries such as Italy, Spain and Greece children spent few hours in paid child care. A surprisingly high percentage of women in these countries stay at home and use non-parental child care arrangements. We have two opposite conclusions concerning these countries: on one hand women are discouraged to use child care in these countries maybe due to a strong family tradition where the woman is the milestone in the house and on the other hand women do not want to enter in the labour market not because children are an obstruction but because other reasons prevail.

Women's labour supply and child care arrangements are influenced by a change in the wage rate. The results indicate that hourly wages have 
a strong effect on the decision to work and to use paid and unpaid child care. Policies that increase the effective wage rate, such as benefits for poor families or less penalization in terms of taxation for married women are likely to have a significant effect on employment status.

The rate of married women that work at home is very high in Mediterranean countries. New solutions to involve women in the labour market are needed. 


\section{$7 \quad$ References}

Addabbo, T., Olivier, F., 2002, Offerta di Lavoro e Servizi allInfanzia in Italia - leffetto dellintroduzione dellISE, WP. 381, Modena, Centro di Analisi delle Politiche Pubbliche.

Angrist, J.D. and Evans, W., 1998, Children and their parents labour supply: evidence from exogenous variation in family size, The American Economic Review 88(3): 450-477.

Alvarez B., Miles D. Husbands Housework Time: Does Wives Paid Employment Make a Difference? Investigaciones Economicas. vol. XXX (1), 2006, 5-31 Becker, G., 1981, A Treatise on the Family, Harvard University Press.

Blau, D. M., 1991, The Economics of Child Care, Russel Sage New York. [7] Blau, D., P. Robins, 1988, Child Care Costs and Family Labour Supply, Review of Economics and Statistics, Vol. 70, n. 3, pp. 374-81.

Blau, D., P. Robins, 1998, A Dynamic Analysis of Turnover in Employment and Child Care, Demography, 35(1) 83-96.

Bianchi, S.M., M.A. Milkie, L.C. Sayer and J.P. Robinson (2000): Is anyone doing the housework? Trends in the gender division of household labour, Social Forces 79, pp. 191-228.

Bratti M, Del Bono E., and Vuri D., 2003, Work Attachment of New Mothers: the Role of Human Capital, Employment Stability and Job Protection in Italy

Carrasco C, Rodriguez A (2000): Women, Families, and Work in Spain: Structural Changes and New Demands. Feminist Economics 6(1):4557 
Del Boca, D., (2002), The Effect of Child care and Part Time Opportunities on Participation and Fertility Decisions in Italy, Discussion Paper No. 427, IZA.

Del Boca, D. Viuri D., (2002), The mismatch between employment and childcare in Italy: the impact of rationing, Journal of Population of Economics 2007.

Di Tommaso, M.L., (1999), A Trivariate Model of Participation, Fertility and Wages: The Italian Case, Cambridge Journal of Economics, 23, 5: 62340.

Esping-Andersen 1990. The Three Worlds of Welfare Capitalism, Princeton, NJ: Princeton University Press.

Eurostat (2002): Women and men reconciling work and family life,, Statistics in Focus, Population and Social Conditions, Theme 3-9/2002.

European Commission (1998), Equal opportunities for women and men in Europe? Eurobarometer 44.3-Results of an opinion survey, Luxembourg.

Shelton, B.A. (1990): The distribution of housework tasks: Does wifes employment status make a di..erence?, Journal of Family Issues 11, pp. 115135 .

South and Spitze (1994): Housework in marital and nonmarital households, American Journal of Sociology 93, pp. 659-687.

Ribar D. (1991): Child Care and the Labor Supply of married Women,Journal Of Human Resources XXVII

Van der Lippe, T. and J.J. Siegers (1994): Division of household and paid labour between partners: E..ects of rbelative wage rates and social norms, Kyklos 47, pp. 109-136. 
Windmeijer, F.A.G. and J.M.C. Santos Silva (1997): Endogeneity in count data models: An application to demand for health care, Journal of Applied Econometrics 12, pp. 281-294. 


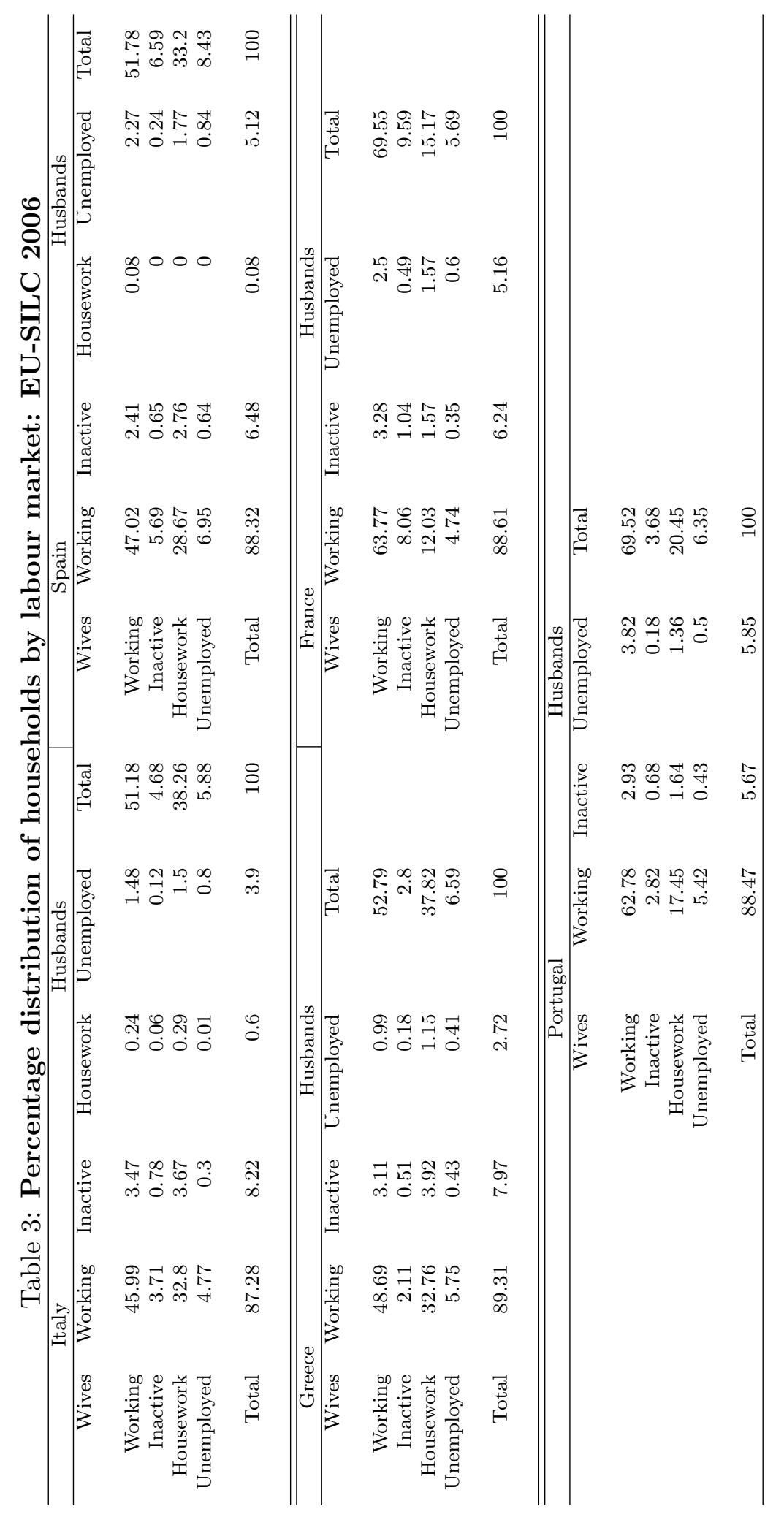




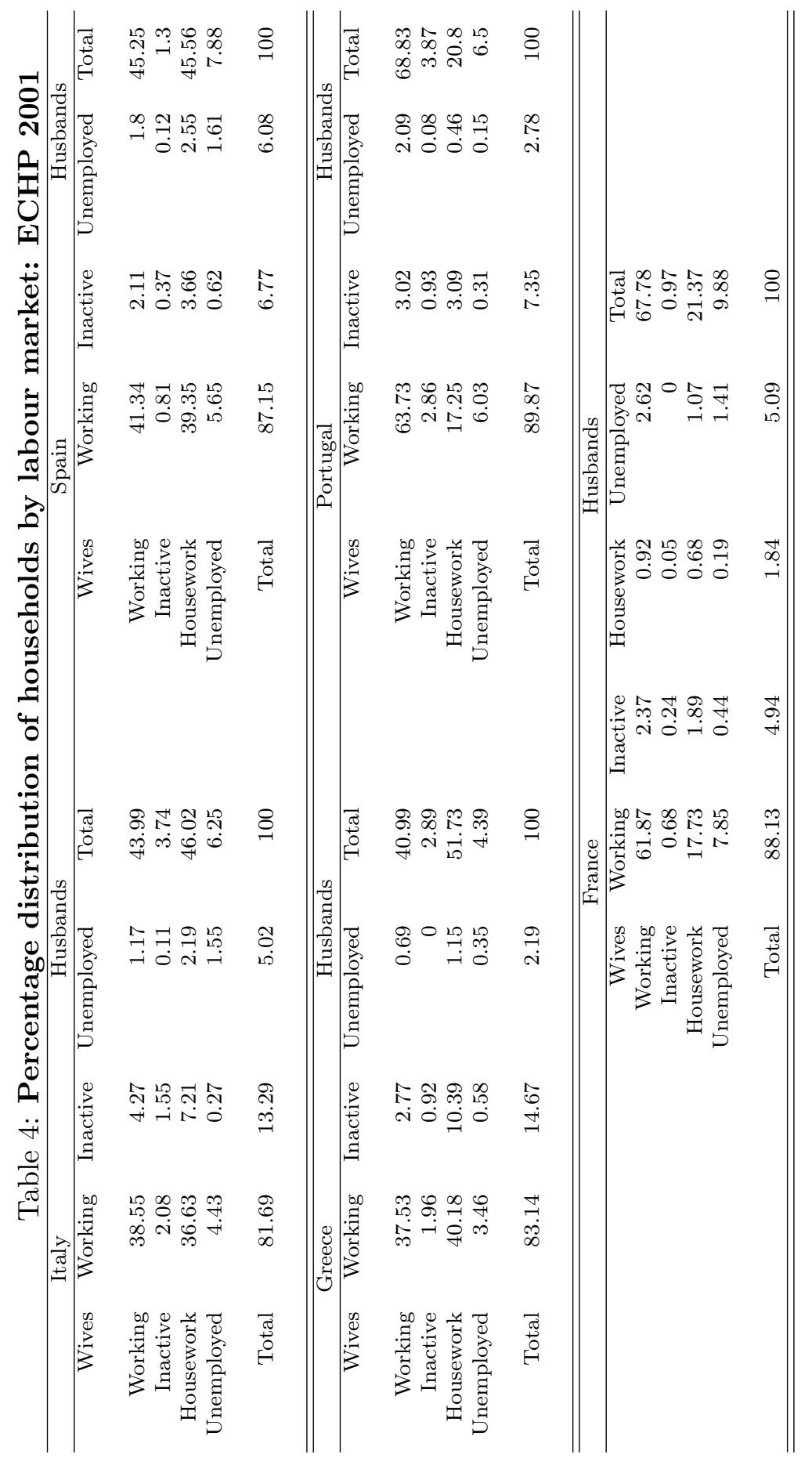


Table 5: Distribution between couple of the numbers of hours and is they take care of the children: ECHP 2001

\begin{tabular}{|c|c|c|c|c|c|c|c|c|}
\hline Greece & \multicolumn{4}{|c|}{ Husbands } & & \multicolumn{3}{|c|}{ Wives } \\
\hline Wives & $<14$ & $14-28$ & $>28$ & Total & & & & \\
\hline$<14$ & 2.02 & 0.51 & 0 & 2.53 & Husbands & Yes & No & Total \\
\hline $14-28$ & 11.62 & 6.57 & 0 & 18.18 & Yes & 41.11 & 0.58 & 41.7 \\
\hline$>28$ & 17.68 & 45.96 & 15.66 & 79.29 & No & 35.89 & 22.42 & 58.3 \\
\hline Total & 31.31 & 53.03 & 15.66 & 100 & Total & 77 & 23 & 100 \\
\hline Spain & \multicolumn{4}{|c|}{ Husbands } & & \multicolumn{3}{|c|}{ Wives } \\
\hline Wives & $<14$ & 14-28 & $>28$ & Total & & & & \\
\hline$<14$ & 2.71 & 1.08 & 0.27 & 4.07 & Husbands & Yes & No & Total \\
\hline $14-28$ & 2.98 & 2.98 & 1.36 & 7.32 & Yes & 50.34 & 0.75 & 51.09 \\
\hline$>28$ & 11.65 & 33.88 & 43.09 & 88.62 & No & 25.7 & 23.21 & 48.91 \\
\hline Total & 17.34 & 37.94 & 44.72 & 100 & Total & 76.04 & 23.96 & 100 \\
\hline Italy & \multicolumn{4}{|c|}{ Husbands } & & \multicolumn{3}{|c|}{ Wives } \\
\hline Wives & $<14$ & 14-28 & $>28$ & Total & & & & \\
\hline$<14$ & 3.75 & 0.34 & 0.17 & 4.26 & Husbands & Yes & No & Total \\
\hline $14-28$ & 12.1 & 7.67 & 0.51 & 20.27 & Yes & 37.16 & 1.98 & 39.14 \\
\hline$>28$ & 19.25 & 35.95 & 20.27 & 75.47 & No & 32.3 & 28.56 & 60.86 \\
\hline Total & 35.09 & 43.95 & 20.95 & 100 & Total & 69.46 & 30.54 & 100 \\
\hline France & \multicolumn{4}{|c|}{ Husbands } & & & & \\
\hline Wives & $<14$ & 14-28 & $>28$ & Total & & \multicolumn{3}{|c|}{ Wives } \\
\hline$<14$ & 6.59 & 0.6 & 0.6 & 7.78 & Husbands & Yes & No & Total \\
\hline $14-28$ & 13.77 & 11.98 & 0 & 25.75 & Yes & 63.96 & 1.16 & 65.12 \\
\hline$>28$ & 16.17 & 26.95 & 23.35 & 66.47 & No & 14.4 & 20.48 & 34.88 \\
\hline Total & 36.53 & 39.52 & 23.95 & 100 & Total & 78.36 & 21.64 & 100 \\
\hline Portugal & \multicolumn{4}{|c|}{ Husbands } & & \multirow{2}{*}{\multicolumn{3}{|c|}{ Wives }} \\
\hline Wives & $<14$ & $14-28$ & $>28$ & Total & & & & \\
\hline$<14$ & 6.59 & 0.6 & 0.6 & 7.78 & Husbands & Yes & No & Total \\
\hline $14-28$ & 13.77 & 11.98 & 0 & 25.75 & Yes & 59.15 & 0.54 & 59.69 \\
\hline$>28$ & 16.17 & 26.95 & 23.35 & 66.47 & No & 27.1 & 13.2 & 40.31 \\
\hline Total & 36.53 & 39.52 & 23.95 & 100 & Total & 86.25 & 13.75 & 100 \\
\hline
\end{tabular}




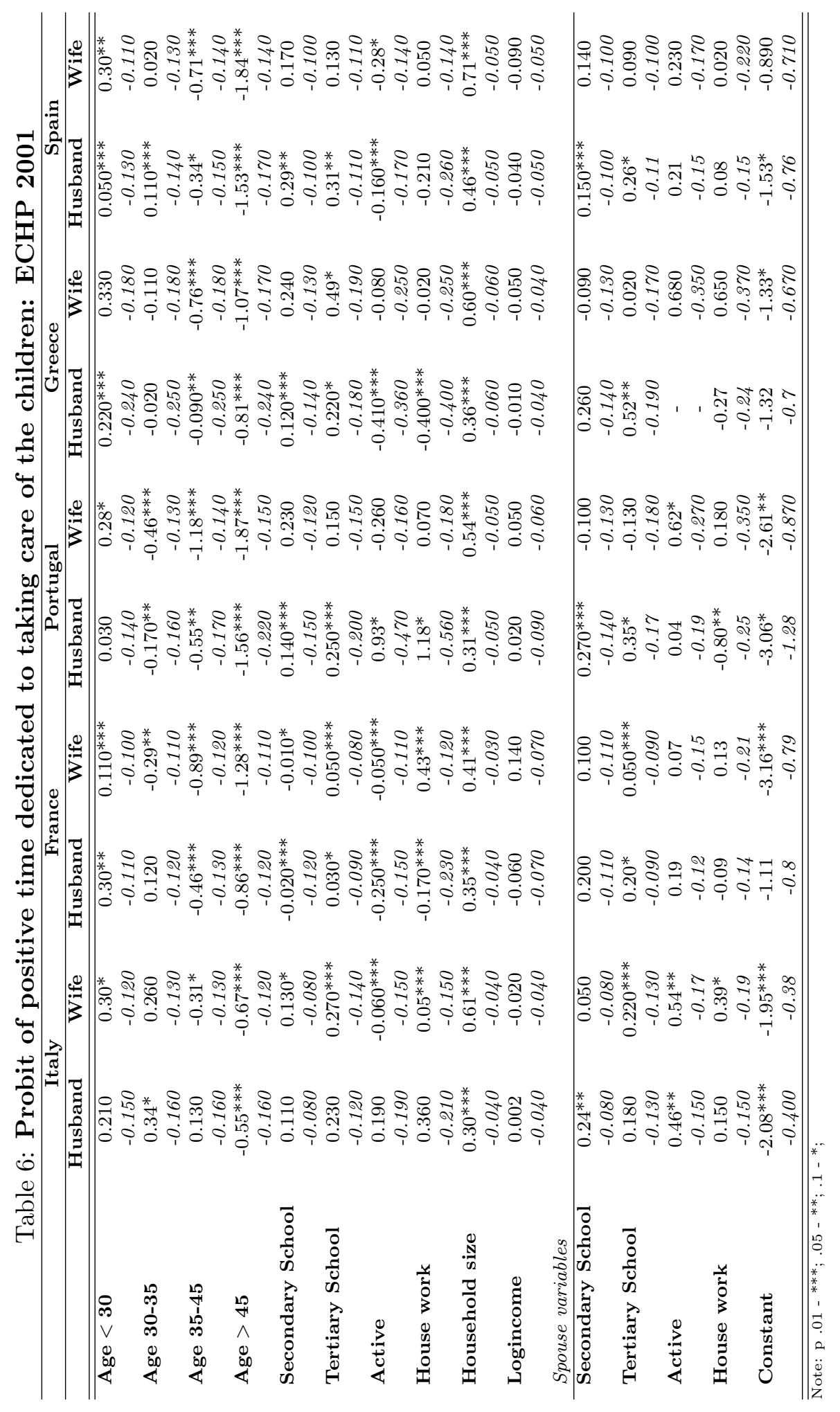




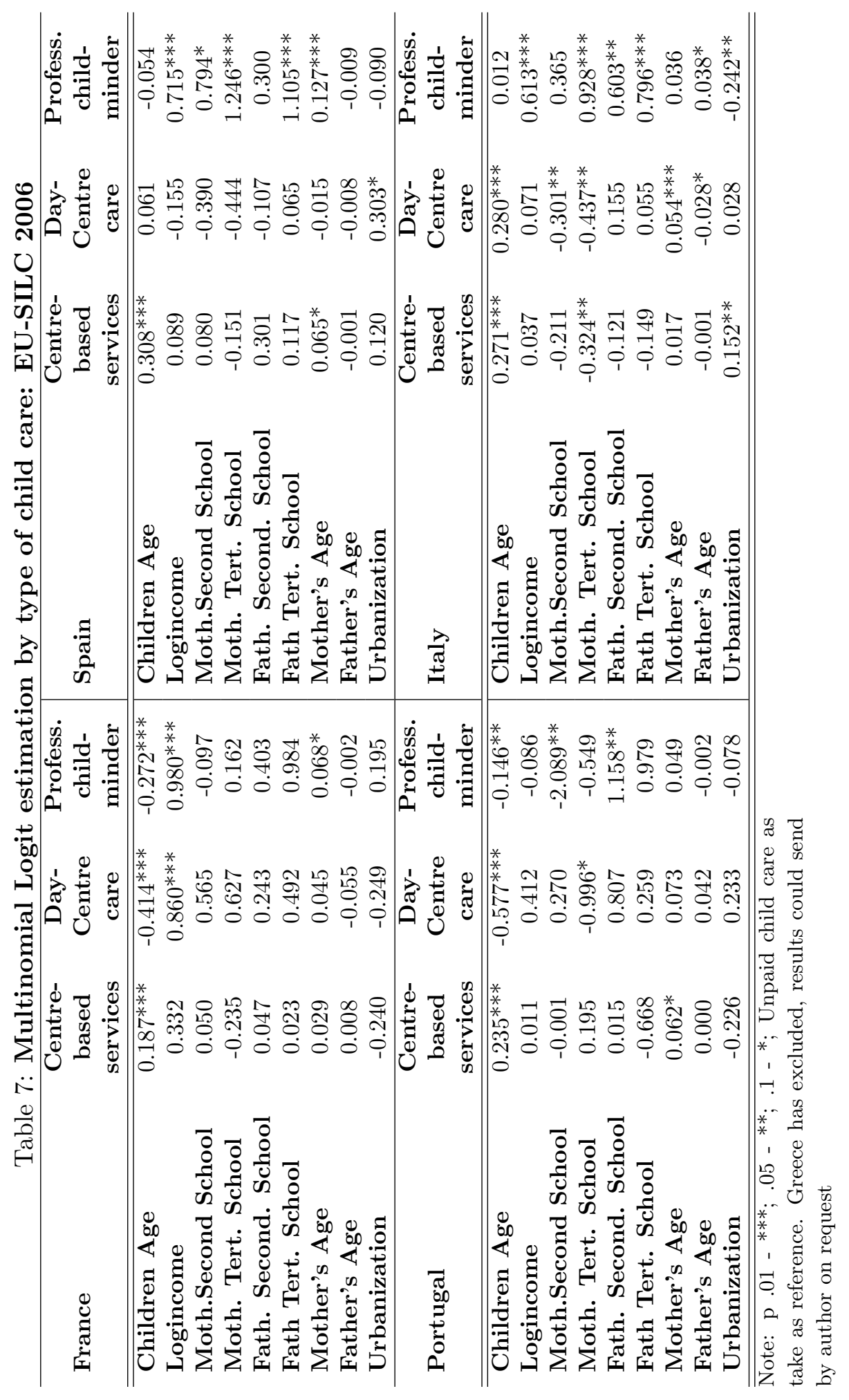


Table 8: Joint Estimation of Child Care and Participation of Women: Italy, EU-SILC 2006

\begin{tabular}{|c|c|c|c|}
\hline & $\begin{array}{c}\text { Mother's } \\
\text { Employm. } \\
\text { Status }\end{array}$ & $\begin{array}{c}\text { Hours of } \\
\text { Paid Child } \\
\text { care }\end{array}$ & $\begin{array}{l}\text { Hours of } \\
\text { Unpaid } \\
\text { Child care }\end{array}$ \\
\hline Age & $\begin{array}{c}0.10^{* * *} \\
-0.02\end{array}$ & $\begin{array}{c}4.37^{* * *} \\
-0.45\end{array}$ & $\begin{array}{c}6.65^{* * *} \\
-0.67\end{array}$ \\
\hline Age squared & $\begin{array}{c}-0.01^{* * *} \\
0\end{array}$ & $\begin{array}{c}-0.63^{* * *} \\
-0.06\end{array}$ & $\begin{array}{c}-1.07 * * * \\
-0.09\end{array}$ \\
\hline Second. Edu. & $\begin{array}{l}0.07^{*} \\
-0.03\end{array}$ & $\begin{array}{c}1.97^{* * *} \\
-0.56\end{array}$ & $\begin{array}{l}1.96^{*} \\
-0.91\end{array}$ \\
\hline Tertiary Edu. & $\begin{array}{c}0.12^{* *} \\
-0.04\end{array}$ & $\begin{array}{c}3.49^{* * *} \\
-0.7\end{array}$ & $\begin{array}{c}4.18^{* * * *} \\
-1.13\end{array}$ \\
\hline Second Edu. Husban. & $\begin{array}{c}0.45^{* * *} \\
-0.03\end{array}$ & $\begin{array}{c}1.51^{* *} \\
-0.57\end{array}$ & $\begin{array}{c}5.67^{* * *} \\
-0.94\end{array}$ \\
\hline Tertiary Edu. Husban. & $\begin{array}{c}1.01^{* * *} \\
-0.04\end{array}$ & $\begin{array}{c}4.92^{* * *} \\
-0.68\end{array}$ & $\begin{array}{c}10.60^{* * *} \\
-1.13\end{array}$ \\
\hline Income & $\begin{array}{c}0.05^{* *} \\
-0.02\end{array}$ & $\begin{array}{c}0.6 \\
-0.37\end{array}$ & $\begin{array}{l}1.07 \\
-0.6\end{array}$ \\
\hline Child. Age 0-3 & $\begin{array}{c}0.03 \\
-0.05\end{array}$ & $\begin{array}{c}-7.86^{* * *} \\
-0.97\end{array}$ & $\begin{array}{c}9.05^{* * *} \\
-1.2\end{array}$ \\
\hline Child. Age 4-6 & $\begin{array}{c}0.06 \\
-0.04\end{array}$ & $\begin{array}{l}-0.36 \\
-0.67\end{array}$ & $\begin{array}{c}8.93^{* * *} \\
-1.04\end{array}$ \\
\hline Unemp of Husband & $\begin{array}{c}0.30 * * * \\
-0.07\end{array}$ & $\begin{array}{c}-0.2 \\
-1.35\end{array}$ & $\begin{array}{c}-4.68^{*} \\
-2.38\end{array}$ \\
\hline House Size & $\begin{array}{c}-0.15^{* * *} \\
-0.01\end{array}$ & $\begin{array}{l}-0.49 \\
-0.26\end{array}$ & $\begin{array}{c}-1.51^{* * *} \\
-0.43\end{array}$ \\
\hline Metropolitan Area & $\begin{array}{c}0.12^{* * *} \\
-0.02\end{array}$ & $\begin{array}{l}0.25 \\
-0.3\end{array}$ & $\begin{array}{l}0.62 \\
-0.5\end{array}$ \\
\hline$\sigma$ & $\begin{array}{c}2.66^{* * *} \\
-0.02\end{array}$ & & \\
\hline$\rho_{12}$ & $\begin{array}{c}0.13^{* * *} * \\
-0.02\end{array}$ & & \\
\hline$\rho_{13}$ & $\begin{array}{c}0.40 * * * \\
-0.02\end{array}$ & & \\
\hline$\rho_{23}$ & $\begin{array}{c}0.30^{* * *} \\
-0.02\end{array}$ & & \\
\hline
\end{tabular}


Table 9: Joint Estimation of Child Care and Participation of Women: Italy, EU-SILC 2006

\begin{tabular}{|c|c|c|c|}
\hline & $\begin{array}{c}\text { Mother's } \\
\text { Employm. } \\
\text { Status }\end{array}$ & $\begin{array}{c}\text { Hours of } \\
\text { Paid Child } \\
\text { care }\end{array}$ & $\begin{array}{l}\text { Hours of } \\
\text { Unpaid } \\
\text { Child care }\end{array}$ \\
\hline \multirow[t]{2}{*}{ Age } & $0.55^{*}$ & $3.71^{* * *}$ & $5.79 * * *$ \\
\hline & 0.24 & -0.52 & -0.73 \\
\hline \multirow[t]{2}{*}{ Age squared } & $-0.06^{*}$ & $-0.57 * * *$ & $-1.02 * * *$ \\
\hline & -0.03 & -0.07 & -0.1 \\
\hline \multirow[t]{2}{*}{ Hourly wage } & $0.14^{* * *}$ & $0.14 * * *$ & $0.46^{* * *}$ \\
\hline & -0.02 & -0.03 & -0.05 \\
\hline \multirow[t]{2}{*}{ Second. Edu. } & -0.6 & $2.38^{* * *}$ & 0.85 \\
\hline & -0.33 & -0.63 & -0.91 \\
\hline \multirow[t]{2}{*}{ Tertiary Edu. } & $-0.16^{* *}$ & $3.65 * * *$ & $3.15^{* *}$ \\
\hline & -0.41 & -0.78 & -1.12 \\
\hline \multirow[t]{2}{*}{ Second Edu. Husban. } & $-0.53^{* * *}$ & $-2.84^{* *}$ & $-6.80 * * *$ \\
\hline & -0.59 & -1.05 & -1.58 \\
\hline \multirow[t]{2}{*}{ Tertiary Edu. Husban. } & $-0.13^{* * *}$ & -3 & $-15.52^{* * *}$ \\
\hline & -0.97 & -1.73 & -2.65 \\
\hline \multirow[t]{2}{*}{ Income } & $1.39 * * *$ & 0.02 & 0.66 \\
\hline & -0.26 & -0.5 & -0.75 \\
\hline \multirow[t]{2}{*}{ Child. Age 0-3 } & -0.1 & $-7.69 * * *$ & $7.90 * * *$ \\
\hline & -0.54 & -1.04 & -1.18 \\
\hline \multirow[t]{2}{*}{ Child. Age 4-6 } & -0.53 & -0.18 & $7.29 * * *$ \\
\hline & -0.45 & -0.74 & -1.03 \\
\hline \multirow[t]{2}{*}{ Hourly wage Husban. } & $-0.01 * * *$ & 0.01 & 0.02 \\
\hline & 0 & 0 & -0.01 \\
\hline \multirow[t]{2}{*}{ House Size } & $-0.86 * * *$ & 0.08 & -0.64 \\
\hline & -0.17 & -0.3 & -0.44 \\
\hline \multirow[t]{2}{*}{ Metropolitan Area } & 0.16 & -0.52 & -0.97 \\
\hline & -0.18 & -0.35 & -0.51 \\
\hline \multirow[t]{2}{*}{$\sigma$} & $2.70 * * *$ & & \\
\hline & -0.03 & & \\
\hline \multirow[t]{2}{*}{$\rho_{12}$} & 0.12 & & \\
\hline & -0.09 & & \\
\hline \multirow[t]{2}{*}{$\rho_{13}$} & $0.28 * * *$ & & \\
\hline & -0.08 & & \\
\hline \multirow[t]{2}{*}{$\rho_{23}$} & $0.22^{* * *}$ & & \\
\hline & -0.03 & & \\
\hline
\end{tabular}

